\title{
GDP Alone Predicts Income and Survival
}

\author{
Gordon Bechtel ${ }^{1}$, Timothy Bechtel ${ }^{2 *}$ \\ ${ }^{1}$ Warrington College of Business, University of Florida, Gainesville, USA \\ ${ }^{2}$ Aviation Power GmbH, Frankfurt, Germany \\ Email: *bechtel@ufl.edu
}

How to cite this paper: Bechtel, G., \& Bechtel, T. (2021). GDP Alone Predicts Income and Survival. Open Journal of Social Sciences, 9, 487-493.

https://doi.org/10.4236/jss.2021.91034

Received: December 15, 2020

Accepted: January 26, 2021

Published: January 29, 2021

Copyright $\odot 2021$ by author(s) and Scientific Research Publishing Inc. This work is licensed under the Creative Commons Attribution International License (CC BY 4.0).

http://creativecommons.org/licenses/by/4.0/ (c) (i) Open Access

\begin{abstract}
This article generalizes Bechtel and Bechtel (2020a, 2020b). The results in these papers induce our hypotheses that GDP predicts income and survival. These hypotheses are confirmed at the global level and we invite the G20 to confirm them at the national level as well. Our regressions show that global life expectancy and global gross income per capata can be predicted from GDP alone without survey sampling, questionnaire interrogation, probabilistic inference, or significance testing. In view of trade-war and COVID-19 shocks to the world economy, international attention to GDP's life-saving effects is now compelling.
\end{abstract}

\section{Keywords}

Bilinear OLS Regression, Ghandian Economics, Gross Global Income (GGI) per Capata, Life Expectancy at Birth, Pandemic Threats to Lives and Economies

\section{Survival and Ghandian Economics}

Mahatma Ghandi rejected the concept that underlies classical economic thinking; namely that "the human being is a rational actor always seeking to maximize material self-interest [...] His model, by contrast, is aimed at the fulfillment of needs-including the need for meaning and community [...] Ghandi's concept of egalitarianism was centered on the preservation of human dignity rather than material development". (cf. Internet Explorer: Mahatma Ghandi-Wikipedia.) Ghandian egalitarianism mitigated institutionalized inequality that induced poverty and threatened life itself.

In pursuing his agenda, Ghandi advocated local, ground-up creation and ownership of companies rather than control of the supply side by international conglomerates. His major, and revolutionary, economic activity centered on the manufacture of apparel in localities throughout India and South Africa, supplying 
their poor and hungry populations. Ghandi's profitable enterprises in these huge BRICS nations epitomized his egalitarian philosophy of status-quo reform by beginning with whatever the real economy presents. His successful deployment of bottom-up capitalism outmatched the top-down efforts of the British empire in its failing attempt to control India and the rest of the planet.

A Moment of Truth and Hope. Mahatma Ghandi's bottom-up capitalism is now updated by The United Nation's Secretary General Antonio Guterres, who advocates corrections to the World Bank, the International Monetary Fund, and the UN Security Council. Guterres stresses that events have overtaken us (http://www.nelsonmandela.org/content/page/annual-lecture-2020):

- The corona virus has brought the world to the breaking point and exposed deep demographic inequalities.

- A new UN governance would give each nation an equal vote and no veto.

- A new social contract would create equal opportunity at all institutional levels.

- An inclusive and balanced multilateral trading system would provide sustenance and sustainability.

Guterres reiterated these issues at the United Nations $75^{\text {th }}$ anniversary on September 21, 2020. Pursuing "the future we want, the United Nations we need", the UN passed a Declaration of International Collaboration advocating an egalitarian reformation of the UN as well as the entire global establishment. Ten weeks later Guterres implicitly admonished some of the G20 nations for their rejection and ignorance of the World Health Organization's information and guidance in addressing poor nation's poverty, hunger, and survival in the COVID-19 pandemic: "When countries go in their own direction, the virus goes in every direction". Pivoting to climate change, Guterres then requested governments to declare climate emergencies in their own countries: "This is a moment of truth and it is also a moment of hope".

The present paper. In view of Ghandi's and Guterres' lessons, and COVID19 's medical and economic threats, we focus on income in dollars and survival in years as our dependent variables. Our operational definitions of these variables are life expectancy at birth and gross global income (GGI) per capata. We show that GDP perfectly predicts these imperatives at the global level and invite the G20 to replicate our results at the national level as well.

Section 2 describes GDP's three components and, we believe for the first time, documents their internal consistency. Section 3 develops a theory of imperatives in which income and survival are the most important special cases. Section 4 brings this theory to bear on these two cases. Section 5 discusses our results visa'-vis global data science, the trade war, and the 2020 pandemic.

\section{GDP in the Global Establishment}

History of GDP. In the great depression Simon Kuznetz formulated American national accounts in terms of dollars, which evaluated different commodities in a common unit. He added up various national income sources and reported 
his result to the United States Senate in January, 1934 (Masood, 2016, Prologue, Chapters 2 and 3). "In 1940, six years after Simon Kuznetz had presented his national income estimates to the Senate, Keynes had written down in a table the basis for what today is the formula for GDP” (Masood, 2016: p. 26). This formula adds up three macro indicators, household expenditure, domestic savings, and government expenditure, which constitute Keynesian GDP.

Importance of GDP. In 1999, mindful of Simon Kuznets original accounting of distinct goods like cars and cereal boxes by their dollar values (Masood, 2016, Introduction), the United States Commerce Department proclaimed the GDP formula as the U.S. government's greatest invention of the $20^{\text {th }}$ century. The calibration of GDP's three indicators in current US dollars for all nations signals a continuing American control of the global economy.

In the plethora of global indexes, GDP looms as the composite most fundamental to the global economy. GDP is so basic, longstanding, and prestigious that market traders, analysts, and policy planners track it daily on worldwide television and internet. The new empirical economics is dominated by GDP's "Making the Modern World" (Masood, 2016, Preface), it's fostering human development, and it's availability in most national accounts (Bechtel, 2019).

Here we view GDP's components, household expenditure, domestic savings, and government expenditure, as separate time-varying indicators (http://beta.data.worldbank.org):

Indicators of GDP. "Household final consumption expenditure (formerly private consumption) is the market value of all goods and services, including durable products (such as cars, washing machines, and home computers), purchased by households. It excludes purchases of dwellings but includes imputed rent for owner-occupied dwellings. It also includes payments and fees to governments to obtain permits and licenses. Here, household consumption expenditure includes the expenditures of nonprofit institutions serving households, even when reported separately by the country. Data are in current U.S. dollars."

"Gross domestic savings are calculated as GDP less final consumption expenditure (total consumption). Data are in current US dollars."

The World Bank's update of John Maynard Keynes final indicator, added during World War II (Keynes, 1940), is:

"General government final consumption expenditure (formerly general government consumption) includes all current government expenditures for purchases of goods and services (including compensation of employees). It also includes most expenditures on national defense and security, but excludes government military expenditures that are part of government capital formation. Data are in current US dollars" (italic ours).

The dollar denomination of variables counted in different units (automobiles, cereal boxes, etc.) allows the ratio scaling of GDP up to a multiplier calibrating GDP in single, thousands, millions, billions, or trillions of current US dollars. 
This ratio scaling also allows daily exchange rates to multiply one nation's currency into another's (e.g. dollars into yen).

Internal Consistency of GDP Indicators. Table 1 displays the correlations among GDP's three global indicators (http://beta.data.worldbank.org):

If the three off-diagonal correlations in Table 1 were also 1.0000 , then unweighted global GDP would take the form

$$
1 \text { * Consum }+1 \text { * Gov }+1 \text { * Sav, }
$$

and would correlate 1.0000 over time with any weighted linear combination

$$
a^{\star} \text { Consum }+b^{*} \text { Gov }+c^{*} \text { Sav. }
$$

Table 1 shows that global GDP approachs the ideal of a perfect, internally-consistent index (cf. Bechtel, 2019).

\section{Theory Testing}

Linear Axiom 1.

$$
\mathrm{Y}=\alpha 1+\beta \mathrm{X}
$$

where 1 is the unit vector, $\mathrm{Y}$ and $\mathrm{X}$ are dependent and independent vectors, and scalars $\alpha$ and $\beta$ denote an intercept and a slope.

Axiom 1 will be recognized as the equation for a bilinear ordinary-least-squares (OLS) regression. Axiom 1 is vulnerable to empirical verification and is tested by regressing $\mathrm{Y}$ on $\mathrm{X}$, each of which are measured over successive time points.

Operational Definition 1. Income is gross global income (GGI) per capata in current US\$. The first line of Table 2 displays the intercept, slope, and $\mathrm{R}^{2}$ of our regression of income on global GDP values from 1990 through 2018. Intercepts and slopes are calibrated in current US\$ for income $\mathrm{Y}$ and trillions of current US\$ for GDP X. Vectors $\mathrm{Y}$ and X are importance-weighted by a vector $\mathrm{P}$, which denotes national population size, calibrated in billions of individuals, from 1990 through 2018. The sum of these 29 successive global population sizes is 186.672 billion people.

Axiom 1 is resulted by the following command which produces Table 2:

$$
\text { regress } \mathrm{Y} \mathrm{X} \text { [iweight }=\mathrm{P} \text { ], }
$$

Table 1. Internal consistency of global GDP.

\begin{tabular}{cccc}
\hline & Consum & Gov & Sav \\
\hline Consum & 1.0000 & & \\
Gov & 0.9987 & 1.0000 & \\
Sav & 0.9721 & 0.9657 & 1.0000 \\
\hline
\end{tabular}

Table 2. Regressions of income and survival on GDP.

\begin{tabular}{cccc}
\hline Dependent Vector & Intercept & Slope & $\mathbf{R}^{2}$ \\
\hline Income & 1695 current US\$ & 116 current US\$ & 0.9875 \\
Survival & 63.56 years & 0.1065 years & 0.9672 \\
\hline
\end{tabular}


(StataCorp. 2011). Y, X, and P in our Stata dataset were accessed online from World Bank files (http://beta.data.worldbank.org). The first line of Table 2 shows that $\alpha=1695$ current US $\$, \beta=116$ current US $\$$, and $\mathrm{R}^{2}=.9875$, demonstrating that $\mathrm{X}$ almost perfectly fits $\mathrm{Y}$ at the global level. The slope $\beta$ demonstrates that a 1 trillion current US\$ stimulus from global GDP lifts GGI per capata 116 current US\$.

Operational Definition 2. Survival is life expectancy at birth in years. The second line of Table 2 displays the intercept, slope, and $\mathrm{R}^{2}$ of our regression of global life expectancy on global GDP from 1990 through 2018. Intercepts and slopes are calibrated in years for life expectancy $\mathrm{Y}$, and again GDP X is calibrated in trillions of current US\$. The second line of Table 2 shows that $\alpha=63.56$ years, $\beta=0.1065$ years, and $\mathrm{R}^{2}=0.9672$, confirming that global GDP almost perfectly fits global life expectancy as well. The slope in the second line of Table 2 demonstrates that a 1 trillion current US\$ rise in global GDP increases global life expectancy one tenth of a year (1.2 months).

\section{GDP in Global Data Science}

Measurement. Section 4 overrides “The central dogma of statistical inference, that there is a component of randomness in data" (Van Dyke et al., 2015: p. 9). "Neither denying nor quantifying uncertainty, we simply ignore it." (Bechtel, 2018: p. 8). Our axiomatic venture into sequential populations brings compelling advantages to global data science. We replace probabilistic inference by parameter computation and random variables give way to real variables $\mathrm{Y}, \mathrm{X}$, and $\mathrm{P}$. This suggests further "statistical thinking and new foundational frameworks" that help sort out "the many philosophical issues data science presents" (Davidian, 2013). These "philosophical issues" in data science were broached in the last century by Tukey's (1977) Exploratory Data Analysis and Mosteller and Tukey's (1977) Data Analysis and Regression: A Second course in Statistics. In the present paper we make an axiomatic approach to data analysis. Section 3 shows that an axiomatic venture, followed by close model fits, confirm GDP as the world's paramount datum.

Prediction. Table 2 shows that linearly transformed GDP alone predicts income and survival. The attendant computations have been carried out in the absence of survey sampling, questionnaire interrogation, probabilistic inference, or significance testing. In view of trade-war and covid-19 shocks to all economies, international attention to GDP and it's positive effects is now compelling. We invite the G20 to replicate our OLS regressions at the national level with $R^{2} s$ at least 0.95 .

\section{Conclusion}

COVID-19 and World Economies. In his Report to the Congress on 31 March, 2020, the American Federal Reserve Chair Powell noted the "shocking" first quarter drop in Chinese GDP of 36\%. The drop in European GDP was 12\%, and the shrinkage in non-American GDP in the first quarter of 2020 was $13 \%$ 
(https://www.federalreserve.gov/newsevents/testimony/powell20190710a.htm). Six weeks later Powell discussed the Federal Reserve's unprecedented foreign lending to mitigate global GDP contraction (http://www.CNBC.com, 13 May, 2020).

Corroborating the Federal Reserve's concerns, the IMF's Chief Economist Gita Gopinath predicted a drop in global economic outlook in 2020. She also predicted that global GDP will shrink $4.9 \%$ this year. In the second quarter US and German GDP then fell 10\%, the largest quarterly drop for these two nations since WWII. At an annualized rate the American economy has contracted by one third of its value during the COVID-19 pandemic.

COVID-19 and Inequality. Rashawn (2020) commented "There is a saying'When America catches a cold, Black people get the flu.' Well, in 2020, when America catches coronavirus, Black people die. Blacks in about every state with racial data available have higher contraction rates and higher death rates of COVID19."

Addressing the current pandemic at the global level, recent Oxfam data have verified that rich-nation inaction costs, stemming from poor-nation famines, low education, and civil wars, are orders of magnitude greater than the proactive prevention of these tragedies. The United Nations confirms Qxfam that rich countries are not contributing enough to poor countries in the COVID-19 crisis, even though this support protects rich countries too. The UN emphasizes that collaboration between its humanitarian agency, the United States, the IMF, and the World Bank is crucial for mitigating the global GDP contraction that is endangering poor nations. Section 3 here provides data-driven support for this collaboration.

\section{Acknowledgements}

The authors dedicate this work to the memory of their best critic, Maria Cohn Bechtel. Dr. Bethany Bechtel emphasized a gradual Ghandian approach to resolving conflicts and loosening entrenched attitudes about economic innovation. She also stressed the importance of monitoring populations over time to assess economic progress. This article generalizes Bechtel, G. G. and Bechtel, T. G. (2020a and 2020b). The authors thank the reviewer for strengthening this article's content and clarity, and Editor Alice Yao for helping bring our message to the public in this time of crisis.

\section{Conflicts of Interest}

The authors declare no conflicts of interest regarding the publication of this paper.

\section{References}

Bechtel, G. G. (2018). The Human Development Index as Isoelastic GDP: Evidence from China and Pakistan. Economies, 6, 32. https://doi.org/10.3390/economies6020032

Bechtel, G. G. (2019). GDP Is Well-Being. Open Journal of Social Sciences, 7, 189-204. https://doi.org/10.4236/jss.2019.712014

Bechtel, G. G., \& Bechtel, T. G. (2020a). American GDP Alone Predicts Human Devel- 
opment. Advances in Social Sciences Research Journal, 7, 273-282.

https://doi.org/10.14738/assri.79.9012

Bechtel, G. G., \& Bechtel, T. G. (2020b). GDP and Human Development. Open Journal of Social Sciences, 8, 333-343. https://doi.org/10.4236/jss.2020.811030

Davidian, M. (2013). Aren't We Data Science? Amstat News, July, 3-5.

Keynes, J. M. (1940). How to Pay for the War. London: Macmillan.

Masood, E. (2016). The Great Invention: The Story of GDP and the Making and Unmaking of the Modern World. New York: Pegasus Books Ltd.

Mosteller, F., \& Tukey, J. W. (1977). Data Analysis and Regression: A Second Course in Statistics. Reading, MA: Addison-Wesley Pub Co.

Rashawn, R. (2020). Why Are Blacks Dying at Higher Rates from Covid 19? Washington DC: Brookings Institute. https://www.brookings.edu

StataCorp. (2011). Stata Statistical Software, Release 12. College Station, TX: StataCorp LP.

Tukey, J. W. (1977). Exploratory Data Analysis. Reading, MA: Addison-Wesley Pub Co.

Van Dyke, D., Fuentes, M., Jordan, M., Newton, M., Ray, B., Lang, D., \& Wickham, H. (2015). American Statistical Association Statement on the Role of Statistics in Data Science. Amstat News, October, 9. 